\title{
The Impact of Quality Management on Profitability: An Empirical Study
}

\author{
Alexandre Pignanelli \\ Professor • Escola de Administração de Empresas de São Paulo - Fundação Getulio Vargas (FGV-EAESP) \\ alexandre.pignanelli@fgv.br \\ João Mario Csillag \\ Professor \\ Escola de Administração de Empresas de São Paulo - Fundação Getulio Vargas (FGV-EAESP) \\ joao.mario.csillag@fgv.br
}

\begin{abstract}
The article investigates the impact of quality on profitability, following the evolution during a ten years period of 31 firms recognized by Brazilian National Quality Award (PNQ). Data of other companies from the same sectors were also considered, reaching 5354 observations. The statistical analyses included regressions, parametric and non-parametric analyses.
\end{abstract}

KEYWORDS: Quality management, performance, profitability, quality award, empirical research

\section{INTRODUCTION}

A number of empirical studies have been conducted since the 1980's in order to explore the variance of financial performance, taking into consideration factors like firm, industry, year, corporation, and country effects (Rumelt 1991; McGahan and Porter 1997). Usually the results show that the firm effect is the most important, with levels equivalent to approximately three times the ones obtained by the industry effect. These results support the perspective proposed by the Resource-Based View - RBV (Wernerfelt 1984; Rumelt 1984; Barney 1986), which says the main sources of competitive advantages are found in the resources and capabilities of individual firms. Choosing a quality based management model may be seen as one of the internal factors that may differentiate an organization from another and would therefore produce a higher level of performance.

The pioneers and most influential figures of the quality movement during the second half of the twentieth century, such as Deming (1986; 1993), Juran (1964), Feigenbaum (1956) and Crosby (1979), supported the idea that there is a wholesome connection between adopting quality management practices and the financial performance. Nonetheless, this connection has always been based upon anecdotal evidences. Only during the last decade of the century empirical studies have been prioritized by researchers in the fields of operations and strategy, with the objective to show the real effect of quality on financial performance. In Brazil, this field of research has been practically unexplored.

Nevertheless, the analysis of these empirical studies shows results that are not conclusive; some of them show positive effects of quality on financial results, others show the lack of these effects (Powell 1995; Ittner and Larcker 1997; Staw and Epstein 2000; Kaynak 2003; York and Miree 2004). Most of these studies establish a criterion to identify a sample of companies that use the quality management models, and then evaluate its performance by comparing it to a 
second sample that includes companies that do not use these models or companies for which information about the extension of the quality management utilization is not available. Another common proxy found in the empirical studies is validating the relationship between quality practices and performance by way of a proposed theoretical model.

The purpose of this study is to contribute to this discussion in a different manner: instead of considering the difference of performance between the samples, or validate relationships between practices and performance, its main objective is to evaluate the performance of the own companies that effectively adopt quality management, comparing their results in the period after the quality implementation, a stage in which quality management had reached the maturity, with the results of the prior period, the implementation moment of the principles, practices and techniques related with quality.

The next section of this paper provides a brief review on the conceptual development of quality management and an in-depth review on empirical studies conducted on the relationship between quality and financial performance, with emphasis in profitability. The following section presents the research hypothesis. The source of data, the operationalization of the constructs and the method of analysis are described after that. Then, the results obtained are reported and discussed. The final section presents the conclusions and links the main findings to the theoretical references, in addition to discuss the research limitations and to suggest future research possibilities.

\section{LITERATURE REVIEW}

\section{Conceptual approach}

The milestone of the quality movement is commonly related to the activities of some pioneers, known as the founders of the field. In this group one may find Joseph M. Juran (1964), Armand V. Feigenbaum (1956), Phillip B. Crosby (1979) and, specially, William E. Deming $(1986 ; 1993)$ whose work was of great influence on the establishment and evolution of the quality movement.

The concept of Deming's (1986) chain reaction, presented originally in Japan in 1950, advocates, against the common sense of that time, that improving quality would result in direct impact on the productivity and profitability of the firm. Deming's view points out mainly to improvement of product quality and services by reducing uncertainties and variations involved in the project and in the production processes. It was the first "model" that involves quality.

As a fundamental element to his ideas, Deming (1986) presented his famous 14 Points, a set of principles aimed at changing the American management style. Afterwards, Deming (1993) refined this philosophy with his System of Profound Knowledge, especially in the part called Appreciation for a System, which may be interpreted as an extension of the chain reaction concept throughout the whole organization. The System of Profound Knowledge sees the organization as a system formed by many interrelated components that have to work conjointly in order to optimize the system, and not each component individually. The fundamental objective of all managers would be to optimize the system, which would bring, according to Deming, greater longterm benefits to all the stakeholders - customers, shareholders, employees and the society. This holistic view would have strong impact on the evolution of quality during the 90 's, through the models of the national quality awards.

On the academic side, the interest in quality as a management model was consolidated in the first half of the nineties, when the research focus until then prevailing, based on an almost exclusive operation approach, was complemented by a management vision. A symbolic milestone of this period can be associated with a special edition about Total Quality, published by The Academy of Management Review in July' 1994.

In order to meet the demand of establishing theories on quality as a management method, as well as its integration with the business administration theory, as presented by Dean Jr. and Bowen (1994), emerged in this same issue the today's classic article of Anderson, Rungtusanatham and Schroeder (1994), where the authors articulate a theory of business management based on the Deming's philosophy by developing a quality management framework using rigorous methodology. Reeves and Bednar (1994) discuss the evolution of the definition of quality, the strengths and the weaknesses of each one of them, and concluded that multiple definitions should be adopted in order to capture the complexity and the richness of the construct. On the other hand Reger et al. (1994) discuss the difficulties of implementing quality management, given the resistance of the employees when confronted with change. 
On the practical side, the dissemination of quality management models became more intense with the launching of the national quality awards. In order to structure the concepts defended by the pioneers in a model that could be comprehended, deployed and implemented by the American organizations searching for quality and productivity improvement, a group of researchers under the supervision of NIST (National Institute of Standards and Technology) and ASQC (American Society for Quality Control, today ASQ - American Society for Quality), analyzed a series of well succeeded firms in the adoption of the pioneers concepts. These firms were considered in the United States "islands of excellence" because of the success they obtained during the eighties in the competition against the Japanese firms, which were at the height of their influence in America. This study searched for common characteristics that differentiate these firms from the others, resulting in the identification of organizational values easily perceived as a cultural part of these firms, being practiced by their leaders and people from all hierarchical levels. These aspects were considered Core Values to form a management culture oriented toward results and were later deployed in Criteria and Requirements that could be used by other organizations to change its management and to put its performance into a level of excellence (Baldrige National Quality Program 2006).

The systemic structure formed by Requirements, Criteria and Core Values served as a foundation to establish the Malcolm Baldrige National Quality Award, in the United States in 1987 and the Excellence Model of the European Foundation for Quality Management (2003) in 1991. In Brazil, the Excellence Model of National Quality Award (Prêmio Nacional da Qualidade - PNQ) was developed in 1991, based on the American model. From that point it evolved by a process of regular updates conducted by the National Quality Foundation (Fundação Nacional da Qualidade - FNQ) to follow the dynamics of the business management and to reflect the country cultural characteristics (Fundação Nacional da Qualidade 2006).

Today, the PNQ Excellence Model is the basis, along with its Core Values and Criteria (Table 1), for the annual award that recognizes excellence in the implementation of quality management in companies operating in Brazil.
Table 1 - Core Values and Criteria of the Brazilian National Quality Award

\begin{tabular}{|c|c|}
\hline \multicolumn{2}{|c|}{ Core Values } \\
\hline Systemic vision & $\begin{array}{l}\text { Focus on the customer and in the } \\
\text { market }\end{array}$ \\
\hline Organizational learning & Social responsibility \\
\hline Proactivity & Management by fact \\
\hline Innovation & Valuing people \\
\hline $\begin{array}{l}\text { Leadership and constancy of } \\
\text { purpose }\end{array}$ & Process perspective \\
\hline Vision on the future & Results orientation \\
\hline \multicolumn{2}{|c|}{ Criteria } \\
\hline 1 Leadership & 6 People \\
\hline 1.1 Leadership system & 6.1 Work systems \\
\hline 1.2 Culture of excellence & 6.2 Training and development \\
\hline $\begin{array}{l}1.3 \text { Organizational performance } \\
\text { review }\end{array}$ & 6.3 Quality of life \\
\hline 2 Strategy and Plans & 7 Processes \\
\hline 2.1 Strategy development & $\begin{array}{l}7.1 \text { Key business processes and } \\
\text { support processes management }\end{array}$ \\
\hline 2.2 Strategy implementation & $\begin{array}{l}7.2 \text { Supplier relationship } \\
\text { management }\end{array}$ \\
\hline 3 Customers & $\begin{array}{l}\text { 7.3 Economical and financial } \\
\text { management }\end{array}$ \\
\hline 3.1 Image and market knowledge & 8 Results \\
\hline 3.2 Customer relationship & 8.1 Economical and financial results \\
\hline 4 Society & 8.2 Customer and market results \\
\hline $\begin{array}{l}4.1 \text { Social and environmental } \\
\text { responsibility }\end{array}$ & 8.3 Society results \\
\hline $\begin{array}{l}4.2 \text { Ethics and social } \\
\text { development }\end{array}$ & 8.4 People results \\
\hline 5 Information and Knowledge & $\begin{array}{l}8.5 \text { Key business processes and } \\
\text { support processes results }\end{array}$ \\
\hline $\begin{array}{l}5.1 \text { Organizational information } \\
\text { management }\end{array}$ & 8.6 Supplier results \\
\hline $\begin{array}{l}5.2 \text { Comparative information } \\
\text { management }\end{array}$ & \\
\hline 5.3 Intangible assets management & \\
\hline
\end{tabular}

Source: Fundação Nacional da Qualidade 2006, p. 15-18, 23.

More recently, however, that apparent consensus on the benefits of quality is being contested in academia. Two of the main exponents of this criticism are Mary J. Benner and Michael L. Tushman, who published the paper Exploitation, Exploration, and Process Management: The Productivity Dilemma Revisited (2003), which challenges the application of 
process management methods, one of the main Criteria of quality management models (see Table 1). The focus of the researchers goes upon the effect of the process management concepts and methods on the ability of companies to innovate, based upon the concepts of exploration and exploitation introduced by March (1991). Benner and Tushman developed a series of propositions, founded on an extensive review of the theory, which propose that management models that focus on process management support only incremental innovation, aligned with development (exploitation) of skills and positions that already exist, searching to refine and have greater efficiency, opposite to radical innovations, aligned with the discovery of new skills (exploration) and environments open to risks and to experimentation. According to the authors, processes management would bring benefits in situations of favorable context, which include for example the stability of the competitive environment and the acceptance of incremental improvements only. On the other hand, there would not be benefit in situations where dynamic skills and the exploration of unknown variations would be fundamental for success.

\section{Empirical studies}

Despite the existence of a consolidated line of research with focus on the impact of quality on various operational aspects of the firms (Flynn, Schroeder and Sakakibara 1995; Adam Jr 1994; Forza and Filippini 1998; Choi and Eboch 1998; Dow, Samson and Ford 1999), the academic interest about the impact of quality on the financial results is more recent. One seminal work (Powell 1995) had major implications for the areas of operations and strategy.

Powell's empirical research shows that characteristics commonly associated to TQM (Total Quality Management), such as process improvement, benchmarking, and training (also know as "hard TQM") (Rahman 2004), do not produce competitive advantages for the firms, contrary to some tacit, behavior and non imitable characteristics ("soft TQM"), such as organizational culture, empowerment and the leadership commitment. According to Powell, these results support the RBV theory (Dierickx and Cool 1989; Barney 1991; Peteraf 1993). Powell was also the first to challenge the view of quality as a whole, since in his study only three of twelve practices associated to TQM were related to superior performance, therefore suggesting that companies could capture benefits from quality management without necessarily using the whole "TQM ideology".
Mohrman et al. (1995) worked, via questionnaires, with the 500 largest industrial companies and the 500 largest service companies of the United States, according to the Fortune magazine's list. The objective was to investigate the impact of improvement initiatives on the performance of the companies, and the results showed no significant relationship between the adoption of quality management and financial results, operationalized by profitability measures.

Ittner and Larcker (1997) adopted a sample of companies in the automotive and computer industries, with operations in Canada, Germany, Japan and the United States, using profitability as the dependent variable. The main interest of the study was to link processes management techniques to profitability increase. The results do not support the idea that process management contributes as a whole towards the financial performance, but that certain techniques had a positive impact while other ones practically did not influence the performance; to be specific, long term partnerships with suppliers and clients were related to the improvement of profitability, while training, payment based on quality and team work, and the organizational commitment with continuous improvement were not related to higher profitability.

Chenhall (1997) found support for the proposition that relates superior financial performance, operationalized by combined indicators that consider profitability and growth, to the implementation of quality management programs and manufacturing performance measurements. The greatest effects found were the combination of adopting quality management and a management performance evaluation system based on manufacturing indicators. Easton and Jarrell (1998) used a proxy that establish the landmark of the TQM adoption by interviews with companies' representatives and found positive connections between adopting quality management and improvement in growth, profitability and market value.

Wilson and Collier (2000) studied the causal relationship among the different criteria composing the 1995 Malcolm Baldrige National Quality Award criteria utilizing structural equations techniques. The financial performance was taken as an aggregate measure, for which were found evidences of effect of the criteria Process Management and Information and Analysis. The research also concluded that the other criteria did not influence the performance directly, but indirectly by means of its effects on the Process Management and Information and Analysis. 
Staw and Epstein (2000) analyzed the impact of the so called "popular management techniques", among which they include quality management. The research did not find evidence that the companies that adopted and implemented quality management had profits above the average. Nonetheless these companies were admired and seen as more innovative. The top executives of the companies that use these management techniques had a greater pay compared to executives from other companies. According to the authors, the disconnection between reality and image supports the institutional theory, with obvious implications for the agency theory. The widespread use of the "popular management techniques" would be explained by the "bandwagon effect".

Fynes and Voss (2001) found that customer satisfaction is impacted in a positive manner by quality and design practices, although no significant effect was found of the customer satisfaction on the aggregate financial performance, a contradictory result compared with that found by Das et al. (2000). Kaynak (2003) validates a theoretical framework containing associations between quality management practices and performance measures (inventory, quality, market and financial). Cho and Pucik (2005) proposed a theoretical model including quality and also innovation, trying to test the direct effect of these practices, as well as its mediator effects, on growth, profit and market value. The model was tested utilizing structural equations, finding evidence of the relations among quality and profit. But it was not possible to observe the quality effect on growth, except when innovation was present as a mediator effect. The effect on market value was not tested directly, but only together with the moderator effects of growth and profitability.

Nair (2006) was responsible for the first study of meta-analysis regarding the impact of quality on performance, by using data from others 23 published studies. In terms of financial performance, treated as an aggregate variable, the results showed positive effects for leadership, people management, process management and client focus practices. Nonetheless, positive effects were not found for product management, design, supplier management and quality data analysis practices.

As previously remarked, the researches that considered the impact of quality on financial performance on a before-after basis, as proposed by this work, were rare. Hendricks and Singhal (1997) demonstrated improvements in profitability and revenue growth in the long term, for companies that have won quality awards, based on a comparison of the evolution of these variables with a control group.

Interesting results were obtained by York and Miree (2004), showing that Malcolm Baldrige National Quality Award and state quality awards winners had higher profitability than companies from a control group. This was true before and after winning the award, which supports the idea of covariance, and not of a causal relationship, between quality and superior performance.

In Brazil, the empirical studies on the impact of quality on financial performance are scarce. Only the papers of Pignanelli (2006) and Brito, Csillag and Brito (2006) were identified. Pignanelli (2006) used a sample of publicly traded Brazilian companies which were PNQ winners or finalists and investigated the impact of PNQ Criteria use on shareholder wealth maximization, operationalizing this construct by the market value of the firms. The results showed that the evolution of the market value of companies recognized with the award was in line with the average of their industries.

Brito, Csillag and Brito (2006) had access to data of the PNQ evaluation process from 2000 to 2004, which allowed financial performance (profitability and growth) to be studied for three different groups: the winners and finalists of PNQ, firms that went to the second stage of the award evaluation process, and other companies of the same sectors. The findings showed that Brazilian companies that effectively adopt quality management according to FNQ model have profitability above the average of their sectors. On the other hand, the results showed that these same companies present growth rates equivalent to the averages in their sectors.

\section{Hypothesis}

An integrated evaluation of the body of knowledge produced by the empirical researches shows relationships between quality and profitability in many papers, while on the other hand some relevant researches cannot show these relationships. The replication of studies in other settings can contribute and enrich this body of knowledge. Researches with Brazilian data are even more necessary, because the lack of empirical studies of this kind in the country.

Therefore, the objective of this research, presented in the Introduction, was deployed into the following 
hypothesis: "Brazilian companies that effectively implement the principles and techniques associated to quality management have during the post-implementation period higher levels of profitability than in the prior period".

\section{DATA, CONSTRUCTS AND METHODOLOGY}

\section{Data}

The source of information about the performance of companies used in this research was the database Balanço Anual, published by the Brazilian financial newspaper Gazeta Mercantil and updated annually since 1977 with financial results from more than 10,000 companies from many sectors of the Brazilian economy.

The sector classification used by the Annual Balance has its own criteria, with three hierarchical levels. The level used in this work is the most detailed one (level three). The analysis of the Balanço Anual editions from the period covered in this research reveals variations in the definition of these sectors and also in the classification of certain companies. In order to eliminate inconsistencies, in some cases the sectors defined by the Balanço Anual had to be reviewed by the authors.

\section{Constructs}

In empirical studies that associate quality management with performance, the quality construct is normally operationalized by identifying the use of certain management practices with questionnaires and/ or interviews (Powell 1995; Easton and Jarrell 2001; Kaynak 2003) or by recognizing the companies that won quality awards (Hendricks and Singhal 1997; York and Miree 2004).

In this study, the criterion used for representing the effective adoption of quality management was the firm public recognition by FNQ. This recognition is exclusive for companies that have won the PNQ or that have been finalists. This criterion guarantees that only companies with effective implementation of quality management were chosen. The period chosen for the research includes companies recognized since the first cycle in 1992 until the 2006 award cycle. During this period, FNQ recognized 61 firms, out of which 37 of them were finalists and 24 were awarded.

From this initial group, companies that do not have performance data in the Balanço Anual as well com- panies from the financial sector (given to the particularities of performance measurement in this sector), were excluded. Companies recognized two or more times by FNQ were considered only once in this study. In this case the year that offered the largest amount of performance data was chosen, in order to increase the quantity of data available to the analysis. In case of a tie in this criterion, priority was given to the year the firm was recognized as a winner, at a loss to the years it was chosen as finalist.

After these exclusions 31 companies became part of the study sample, identified in Table 2.

Table 2 - Firms, recognition year and sectors USED in the study sample

\begin{tabular}{|c|c|c|}
\hline Firms & Year & Sector \\
\hline ADP Systems & 1992 & Private data processing \\
\hline Águas de Limeira & 2000 & Sanitation \\
\hline Albras & 2005 & Aluminum \\
\hline Alcoa & 1996 & Aluminum \\
\hline Bahia Sul & 2001 & Pulp and paper \\
\hline Belgo & 2004 & Steel \\
\hline Caraíba Metais & 2002 & Metallurgy - other non-ferrous metals \\
\hline Caterpillar & 1999 & $\begin{array}{l}\text { Construction and agricultural } \\
\text { machinery, tractors }\end{array}$ \\
\hline Cetrel & 1999 & Specialized services \\
\hline Copesul & 1997 & Petrochemical products \\
\hline CPFL & 2004 & Energy distribution \\
\hline Credicard & 1992 & Credit cards \\
\hline CST & 1992 & Steel \\
\hline Dana Albarus & 2003 & $\begin{array}{l}\text { Parts, accessories and automotive } \\
\text { components }\end{array}$ \\
\hline Dana Indústrias & 2002 & Engines and components \\
\hline Eaton & 2001 & $\begin{array}{l}\text { Parts, accessories and automotive } \\
\text { components }\end{array}$ \\
\hline Elevadores Atlas & 1999 & Lifts for people and cargo \\
\hline Fras-le & 2006 & $\begin{array}{l}\text { Parts, accessories and automotive } \\
\text { components }\end{array}$ \\
\hline Gerdau & 2002 & Steel \\
\hline IBM & 1992 & Computers, peripherals and copiers \\
\hline Metal Leve & 1992 & Engines and components \\
\hline Petroquímica União & 2005 & Petrochemical products \\
\hline Polibrasil & 2003 & Petrochemical products \\
\hline Politeno & 2001 & Petrochemical products \\
\hline $\begin{array}{l}\text { Promon } \\
\text { Telecomunicações }\end{array}$ & 1997 & Telecommunications \\
\hline $\begin{array}{l}\text { Santa Casa Porto } \\
\text { Alegre }\end{array}$ & 2002 & Hospitals, clinics and laboratories \\
\hline Serasa & 2000 & Specialized services \\
\hline $\begin{array}{l}\text { Siemens - } \\
\text { Telecommunications } \\
\text { Division }\end{array}$ & 1998 & Telecommunications \\
\hline Usiminas & 1995 & Steel \\
\hline WEG & 1997 & $\begin{array}{l}\text { Electric motors, controls and electric } \\
\text { components }\end{array}$ \\
\hline Xerox & 1993 & Computers, peripherals and copiers \\
\hline
\end{tabular}


The use of performance as a dependent variable in empirical studies has been frequently in the areas of operations and strategy. The concern with an adequate use of this variable is reflected in the work of Venkatraman and Ramanujam (1986) that discusses the benefits, the limitations and the methodological aspects for many strategies that use performance in empirical research. March and Sutton (1997) discussed the difficulties of using the performance as a dependent variable, mainly those related to a causal structure which connects organizational characteristics to performance. Glick, Washburn and Miller (2005) evolve the view of Venkatraman and Ramanujam (1986), exploring the concept that the performance may me treated as a one-dimensional construct, a multidimensional construct or a group of diverse constructs.

Most of the studies that consider profitability as a dependent variable in the evaluation of quality management impact on performance, presented in the Literature Review, consider it as a one-dimensional construct, operationalizing it sometimes by return on assets or sometimes by profitability as a percentage of sales. This research chose this last alternative; to be more specific, the option taken was of the relationship between operational profit and net sales. The operational profit was chosen given to the fact that it does not include financial operations, and therefore reflects the ability of the company to generate profit with its primary activities.

The research followed the performance of firms in the sample during a period of ten years. The criterion adopted to divide this interval in the two period mentioned during the hypothesis presentation (before and after implementing quality management) was to define the recognition given to the company as an awarded or finalist by PNQ as evidence that the principles and techniques concerning TQM were effectively implemented. Therefore, the year of recognition was identified as year 0 . The five years prior to this were the implementation period, identified as years $-1,-2,-3,-4$ and -5 . The period that begins with year 0 form the post-implementation period, identified as years $0,+1,+2,+3$ and +4 .

This view about long term performance measurement is supported by the quality literature (Deming 1986; Deming 1993; Juran 1964; Anderson, Rungtusanatham and Schroeder 1994; Hendricks and Singhal 1997), which generally characterizes the implementation stage of quality programs as a period of strong investments and when the first results appear, and the stage of post-implementation as a period of consolidation of results already in higher levels. The excellence models of the quality awards also point to the focus on the long term, as translated, for example, by the PNQ in its Core Value named Vision on the Future:

The organization with vision on the future strategically plans, thinks and learns thus achieving sustained success in its activities. Organization planning should be oriented to long-term success and to current results, without jeopardizing the future due to short-term gains. (Fundação Nacional da Qualidade 2006, p.16)

To calculate the profitability, net sales and operational profit data were collected from the Balanço Anual database for all firms in the study sample and for every other firm of the same sectors, for the period of 10 years that has the year of recognition by FNQ as the base year. Periods of time smaller than 10 years had to be used for the latest winners and finalists. All net sales and operational profit data were registered in the Brazilian currency at the time, and then were adjusted for the currency of January 1st 2007 according to the IPC-A inflation index, supplied by IBGE (Brazilian Institute of Geography and Statistics).

After the data collection, the outliers were eliminated. The rule used was a detailed evaluation of all observations that diverged from more than three standard deviations of the mean. When there was any evidence that the observation presented any sort of balance statement error, a typing error, a different accounting interpretation or an abnormal value, it was eliminated. We also eliminated observations that came from other divisions of a company included in the study sample or from any other PNQ winners or finalists in order to highlight independence.

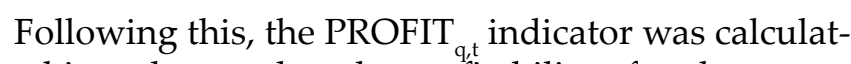
ed in order to relate the profitability of each company in the study sample $\left(\mathrm{P}_{\mathrm{q}}\right)$ with the average profitability of the sector and with the standard deviation of the profitability in the sector, for every year $t$ :

$$
\text { PROFIT }_{q, t}=\frac{P_{q, t}-\bar{P}_{\text {sector,t }}}{S_{\text {sector, },}}
$$

The objective of using PROFIT ${ }_{q, t}$ as explained in the equation is to isolate the sector effect, and therefore allowing comparisons along the years and among the different sectors considered in the study. The 
division by the standard deviation enables PROFIT $_{\mathrm{q}, \mathrm{t}}$ to have higher figures for sectors with smaller performance variance.

Table 3 contains information about data originally collected and about the final data settings.

\section{Table 3 - Observations}

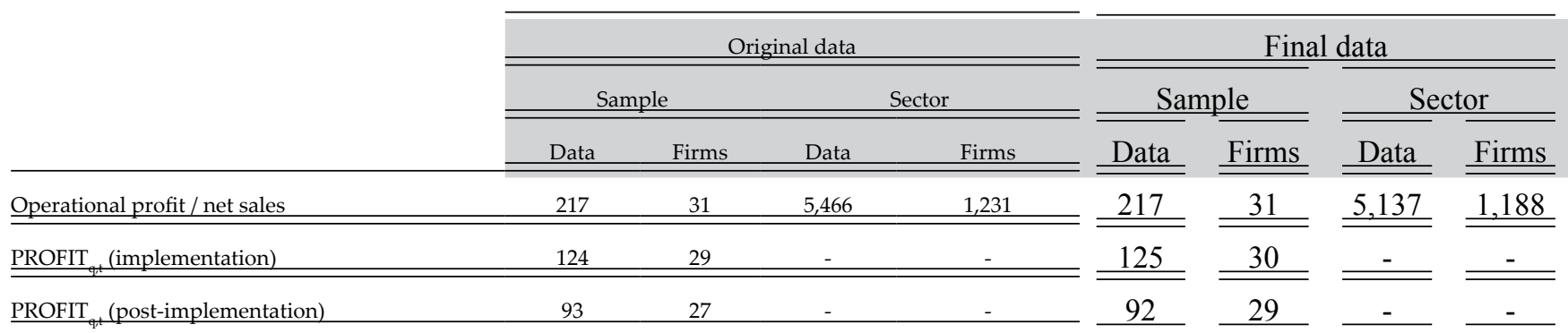

\section{Methodology}

The first stage of the methodology consisted of summarizing the profitability data of each company in the study sample by performing two linear regressions, one for each period established in the hypothesis. The regressions enabled to compare the performance of companies recognized by FNQ in different moments, by allowing the performance in the mid point of each of the two periods to be projected.

The regressions were made with the method of least squares, using the observations from PROFIT ${ }_{q, t}$. Three observations were defined as the minimum number

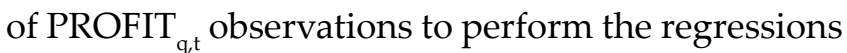
in the implementation and post-implementation period. In order to simplify the interpretation of the linear coefficients of the regressions, an adjustment was made in each of the equations to equalize the intercept (linear coefficient) to the indicator value in the mid point of the period.

Figure 1 summarizes in graphic form the rational involved in the construction of the linear regressions, including the regression equations, for a sample firm where 9 observations of profitability were obtained.

\section{Figure 1 - Linear Regressions}

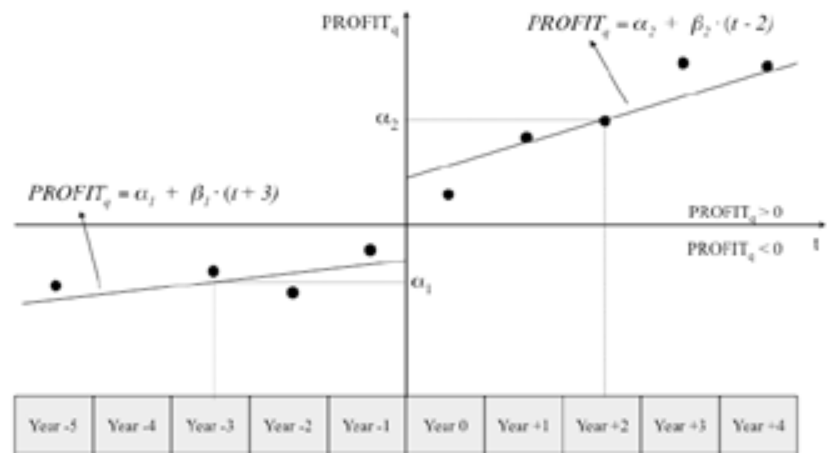

With the coefficients already known for each firm of the study sample, these summarized data were analyzed in a descriptive way, to better understand the distribution and evaluate potential anomalies that could influence further analysis, especially the assumptions of parametric tests.

The next step analyzed the results as a whole, in order to validate or refuse the hypothesis of the research. To do so tests with two different approaches were used: parametric and non-parametric. The parametric approach took place through $t$ tests of the difference between the means of two populations with paired observations. The non-parametric tests are powerful tools when parametric test assumptions cannot be guaranteed. The non-parametric test used was the Wilcoxon signed rank test, specific for related samples and not dependent of distribution assumptions.

\section{RESULTS}

Table 4 shows the results of the linear regressions, in which $\alpha_{\mathrm{i}}$ represents the linear coefficient of the equation - and therefore the profitability in the mid point of each period; and $\mathrm{R}^{2}$ is the coefficient of determination for each regression. 
Table 4 - Linear Regressions

\begin{tabular}{|c|c|c|c|c|}
\hline \multirow{2}{*}{ Firms } & \multicolumn{2}{|c|}{ Implementation period } & \multicolumn{2}{|c|}{$\begin{array}{l}\text { Post-implementation } \\
\text { period }\end{array}$} \\
\hline & $\alpha_{1}$ & $\mathrm{R}^{2}$ & $\alpha_{2}$ & $\mathrm{R}^{2}$ \\
\hline ADP Systems & - & - & -0.327 & 0.218 \\
\hline Águas de Limeira & - & - & 0.570 & 0.000 \\
\hline Albras & 1.170 & 0.019 & - & - \\
\hline Alcoa & -0.495 & 0.566 & 0.178 & 0.670 \\
\hline Bahia Sul & -0.713 & 0.125 & 2.124 & 0.483 \\
\hline Belgo & 1.108 & 0.188 & - & - \\
\hline Caraíba Metais & 0.384 & 0.354 & 0.037 & 0.675 \\
\hline Caterpillar & - & - & - & - \\
\hline Cetrel & - & - & -1.366 & 0.950 \\
\hline Copesul & 0.715 & 0.000 & 0.608 & 0.838 \\
\hline CPFL & 0.317 & 0.796 & - & - \\
\hline Credicard & 0.881 & 0.022 & -0.246 & 0.316 \\
\hline CST & -1.111 & 0.273 & 0.160 & 0.928 \\
\hline Dana Albarus & 0.517 & 0.433 & - & - \\
\hline Dana Indústrias & 0.396 & 0.995 & - & - \\
\hline Eaton & - & - & - & - \\
\hline Elevadores Atlas & 1.342 & 0.085 & -0.193 & 0.039 \\
\hline Fras-le & 0.469 & 0.140 & - & - \\
\hline Gerdau & 0.811 & 0.033 & - & - \\
\hline IBM & - & - & - & - \\
\hline Metal Leve & 0.156 & 0.347 & 0.170 & 0.731 \\
\hline Petroquímica União & 0.107 & 0.176 & - & - \\
\hline Polibrasil & 0.238 & 0.075 & - & - \\
\hline Politeno & 0.766 & 0.611 & 0.525 & 0.548 \\
\hline $\begin{array}{l}\text { Promon } \\
\text { Telecomunicações }\end{array}$ & 0.166 & 0.835 & -0.056 & 0.252 \\
\hline $\begin{array}{l}\text { Santa Casa Porto } \\
\text { Alegre }\end{array}$ & -0.160 & 0.850 & -0.019 & 0.363 \\
\hline Serasa & 0.600 & 0.275 & 0.476 & 0.014 \\
\hline $\begin{array}{l}\text { Siemens - } \\
\text { Telecommunications } \\
\text { Division }\end{array}$ & 0.164 & 0.244 & - & - \\
\hline Usiminas & 0.390 & 0.512 & 1.175 & 0.731 \\
\hline WEG & 0.539 & 0.671 & 0.914 & 0.257 \\
\hline Xerox & -0.448 & 0.567 & - & - \\
\hline
\end{tabular}

The $R^{2}$ data present an average of 0.410 , kurtosis of -1.166 and asymmetry of 0.311 . This profile of distribution, with values occupying the whole range from 0 to 1 , although slightly concentrated to the left, make it so the values found for $\mathrm{R}^{2}$ may be considered satisfactory for the objective of this study.

The main characteristics of the linear coefficient distribution are found in Table 5. Distributions $\alpha_{1}$ and $\alpha_{2}$ have small asymmetries and moderate values of kurtosis, and thus can be considered to be approaching normal distributions.

\section{Table 5}

\section{Descriptive Analysis of the Summarized Data}

\begin{tabular}{lcc} 
Statistics & $\alpha_{1}$ & $\alpha_{2}$ \\
Observations & 25 & 17 \\
Mean & 0.332 & 0.278 \\
Standard deviation & 0.585 & 0.740 \\
Median & 0.390 & 0.170 \\
Asymmetry & -0.633 & 0.411 \\
Kurtosis & 0.477 & 2.416 \\
\hline
\end{tabular}

Finally, Table 6 presents the results of the $t$ tests and the Wilcoxon signed rank tests. The analysis of the data shows that both tests show results that do not allow the rejection, at a level of $5 \%$ of significance, of the null hypothesis in which the profitability of the companies in the study sample does not increase in the post-implementation period, when compared with the profitability in the implementation period. In summary, the results obtained do not allow to validate the hypothesis that Brazilian companies that effectively implemented the principles and techniques of quality management have an increase in their profitability along the studied time.

Table 6 - Parametric and Non-Parametric Tests

\begin{tabular}{|c|c|c|c|}
\hline$t$ test & & Wilcoxon signed $r$ & test \\
\hline Paired observations & 14 & Paired observations & 14 \\
\hline$\alpha_{1}-$ Mean & 0.247 & $\begin{array}{l}\text { Sum of negative } \\
\text { ranks }\end{array}$ & 47 \\
\hline$\alpha_{1}-$ Standard deviation & 0.670 & & \\
\hline$\alpha_{2}-$ Mean & 0.418 & $\begin{array}{l}\text { Sum of positive } \\
\text { ranks }\end{array}$ & 58 \\
\hline$\alpha_{2}-$ Standard deviation & 0.641 & & \\
\hline $\begin{array}{l}\text { Difference between means ( } \\
\left.\bar{\alpha}_{2}-\bar{\alpha}_{1}\right)\end{array}$ & 0.171 & & \\
\hline $\mathrm{t}$ test & 0.608 & Wilcoxon test $(\mathrm{Z})$ & -0.345 \\
\hline $\mathrm{p}$-value & 0.277 & $\mathrm{p}$-value & 0.365 \\
\hline
\end{tabular}




\section{CONCLUSIONS}

The main objective of this research was to evaluate the impact of quality management adoption on the profitability of Brazilian companies, comparing their performance in the period after the effective implementation of quality with the performance prior to that period. In Brazil this type of research approach is still incipient; in other countries the results of studies do not lead to a clear answer regarding the impact of quality on financial performance.

The main finding was the lack of evidence of improved profitability in Brazilian companies that adopted quality management, when comparing the period before and after being recognized by the FNQ. The methodological approach used enables to compare the results with the ones obtained by York and Miree (2004) with data of American companies, coming to similar conclusion: in both cases, high profitability already existed during quality management implementation, and remained high along all the studied period. This fact supports the position of York and Miree (2004) that the relationship between quality and financial performance is a covariation link, and not a causation link. According to this idea, companies that already have superior performance are inclined to adopt quality management models, given to the need to legitimize or to obtain recognition, a favorable organizational environment, or having resources to apply in the necessary investments to finance the quality program.

The following discussion presents possible interpretations for the findings according to the literature review.

A first possible explanation may be found in the work of Benner and Tushman (2003): companies that use quality management, given to the "weight" of the model, would be losing the ability to introduce breakthrough innovation, be agile and flexible, and consequently, to increase its profitability? A revealing fact that seems to support this view is the small participation, or even absence, in the list of companies recognized by FNQ, of companies that work in competitive environments that call for more innovation and agility in order to have success, as is the case of the sectors of food products, pharmaceuticals, home and personal care, communications, entertainment, electronics, customer services, internet and the so called "new economy" as a whole.

Another point that seems to come from the theory and the empirical results is the possible emphasis in the "tool" approach during implementation and evaluation of quality management. This approach focuses excessively on practices, methodologies and standardized procedures, opposite to tacit and behavior characteristics that would be rather closely related to obtaining superior performance (Powell 1995).

This explanation about the tool approach motivates an important discussion involving the analysis of quality theory and the empirical results under Resource-Based View theory. Most of the quality aspects associated with "hard TQM" involve techniques, standards, practices, methodologies and tools that in essence were established to be disseminated throughout companies. This context seems to go against many aspects related to competitive advantages, according to RBV. For example, it is reasonable to suppose that these techniques and tools would be easily obtained in the market of strategic factors explained by Barney (1986), and therefore not favoring the heterogeneousness necessary for competitive differentiation (Wernerfelt 1984). Besides being negotiable, the characteristics of these factors related to quality enable a smooth transference among companies and imitation, and as a result rareness would not take place (Dierickx and Cool 1989; Barney 1991; Peteraf 1993). An aggregate analysis of all of these aspects seems to show a situation not clear enough to obtain competitive advantages.

On the other hand, the characteristics of RBV (heterogeneousness, rareness, imperfect imitation and imperfect mobility) could be associated to this aspects of quality in certain contexts only, as for example in less competitive sectors, less professionalized sectors, less developed regions and companies with inferior management tradition (small and midsized companies, hospitals, schools, agribusiness companies, public sectors and non governmental organizations, for example). In these situations, the tool approach for quality could yet be seen as a strategic resource, resulting in competitive advantages. Not having these types of organizations in the study sample did not allow confirming this fact empirically in this work.

Besides the typical limitations associated with the statistical methods used, this research also has some limitations related to the profile and size of the sample. It is a non-probabilistic sample, and therefore any attempt to generalize the results should be done carefully. Regarding the small sample, nonetheless this limitation is connected to certain characteristics of the study, as the rigor (the proxy for quality 
management considering only firms recognized by FNQ), and the time the quality award started in Brazil (1992, producing until now a small group of winners and finalists).

This research revealed relevant and controversial findings about the relationship between quality and profitability, and discussed possible interpretations of the results according to theoretical concepts. As suggestion to future studies, it would be interesting to replicate this work with a larger sample, including sectors that, according to RBV, as discussed in these Conclusions, would have quality management as a strategic resource to generate competitive advantages. It would be interesting also to broaden the scenario presented here, by using exploratory researches, with primary data, in order to identify and validate the causes associated to the results obtained.

\section{REFERENCES}

Adam Jr, Everett E. (1994), "Alternative Quality Improvement Practices and Organization Performance", Journal of Operations Management, Vol. 12, No. 1, pp. 27-44.

Anderson, John C., Manus Rungtusanatham and Roger G. Schroeder (1994), "A Theory of Quality Management Underlying the Deming Management Method", The Academy of Management Review, Vol. 19, No. 3, pp. 472-509.

Baldrige National Quality Program (2006), Criteria for Performance Excellence, Ed. 2006. Gaithersburg, MD: National Institute of Standards and Technology (NIST).

Barney, Jay B. (1991), "Firm Resources and Sustained Competitive Advantage", Journal of Management, Vol. 17, No. 1, pp. 99-120.

Barney, Jay B. (1986), "Strategic Factor Markets: Expectations, Luck, and Business Strategy", Management Science, Vol. 32, No. 10, pp. 1231-1241.

Benner, Mary J. and Michael L. Tushman (2003), “Exploitation, Exploration, and Process Management: The Productivity Dilemma Revisited", The Academy of Management Review, Vol. 28, No. 2, pp. 238-256.

Brito, Luiz A. L., João M. Csillag and André J. Brito (2006), “Performance Variability and the Relationship with TQM". In: Annual Meeting of the Academy of Management, 2006, Atlanta. Proceedings. Academy of Management.

Chenhall, Robert H. (1997), "Reliance on Manufacturing Performance Measures, Total Quality Management and Organizational Performance", Management Accounting Research, Vol. 8, No. 2, pp. 187-206.

Cho, Hee-Jae and Vladimir Pucik (2005), "Relationship Between Innovativeness, Quality, Growth, Profitability, and Market Value", Strategic Management Journal, Vol. 26, No. 6, pp. 555-575.
Choi, Thomas Y. and Karen Eboch (1998), "The TQM Paradox: Relations Among TQM Practices, Plant Performance, and Customer Satisfaction", Journal of Operations Management, Vol. 17, No. 1, pp. 59-75.

Crosby, Philip B. (1979), Quality is Free: The Art of Making Quality Certain. New York: McGraw-Hill.

Das, Ajay, Robert B. Handfield, Roger J. Calantone and Soumen Ghosh (2000), "A Contingent View of Quality Management - The Impact of International Competition on Quality", Decision Sciences, Vol. 31, No. 3, pp. 649-690.

Dean Jr, James W. and David E. Bowen (1994), “Management Theory and Total Quality: Improving Research and Practice Through Theory Development", The Academy of Management Review, Vol. 19, No. 3, pp. 392-418.

Deming, William E. (1986), Out of the Crisis. Cambridge, MA: Massachusetts Institute of Technology, Center for Advanced Engineering Study.

Deming, William E. (1993), The New Economics for Industry, Government, Education. Cambridge, MA: Massachusetts Institute of Technology, Center for Advanced Engineering Study.

Dierickx, Ingemar and Karel Cool (1989), "Asset Stock Accumulation and Sustainability of Competitive Advantage", Management Science, Vol. 35, No. 12, pp. 1504-1511.

Dow, Douglas, Danny Samson and Steve Ford (1999), “Exploding the Myth: Do All Quality Management Practices Contribute to Superior Quality Performance?", Production and Operations Management, Vol. 8, No. 1, pp. 1-27.

Easton, George S. and Sherry L Jarrell (1998), “The Effects of Total Quality Management on Corporate Performance: An Empirical Investigation", Journal of Business, Vol. 71, No. 2, pp. 253-307.

European Foundation for Quality Management (EFQM) (2003), The Fundamental Concepts of Excellence. Brussels: European Foundation for Quality Management (EFQM).

Feigenbaum, Armand V. (1956), “Total Quality Control”, Harvard Business Review, Vol. 34, No. 6, pp. 93-101.

Flynn, Barbara B., Roger G. Schroeder and Sadao Sakakibara (1995), "The Impact of Quality Management Practices on Performance and Competitive Advantage", Decision Sciences, Vol. 26, No. 5, pp. 659-691.

Forza, Cipriano and Roberto Filippini (1998), “TQM Impact on Quality Conformance and Customer Satisfaction: A Causal Model", International Journal of Production Economics, Vol. 55, No. 1, pp. 1-20.

Fundação Nacional da Qualidade (FNQ) (2006), Critérios de Excelência, Ed. 2006. São Paulo: Fundação Nacional da Qualidade (FNQ).

Fynes, Brian and Chris Voss (2001), "Path Analytic Model of Quality Practices, Quality Performance, and Business Performance", Production and Operations Management, Vol. 10, No. 4, pp. 494-513. 
Glick, William H., Nathan T. Washburn and C. Chet Miller (2005), "The Myth of Firm Performance". In: Annual Meeting of the Academy of Management, 2005, Honolulu. Proceedings. Honolulu: Academy of Management.

Hendricks, Kevin B. and Vinod R. Singhal (1997), “Does Implementing an Effective TQM Program Actually Improve Operating Performance? Empirical Evidence from Firms that Have Won Quality Awards", Management Science, Vol. 43, No. 9, pp. 1258-1274.

Ittner, Christopher D. and David F. Larcker (1997), “The Performance Effects of Process Management Techniques", Management Science, Vol. 43, No. 4, pp. 522-534.

Juran, Joseph M. (1964), Managerial Breakthrough. New York: McGraw-Hill.

Kaynak, Hale (2003), “The Relationship Between Total Quality Management Practices and Their Effects on Firm Performance", Journal of Operations Management, Vol. 21, No. 4, pp. 405-435.

March, James G. (1991), “Exploration and Exploitation in Organizational Learning", Organization Science, Vol. 2, No. 1, pp. 70-87.

March, James G. and Robert I. Sutton (1997), “Organizational Performance as a Dependent Variable", Organization Science, Vol. 8, No. 6, pp. 698-706.

McGahan, Anita M. and Michael E. Porter (1997), "How Much Does Industry Matter, Really?", Strategic Management Journal, Vol. 18, Summer Special Issue, pp. 15-30.

Mohrman, Susan A., Ramkrishnan V. Tenkasi, Edward E. Lawler III and Gerald E. Ledford Jr (1995), “Total Quality Management: Practice and Outcomes in the Largest US Firms", Employee Relations, Vol. 17, No. 3, pp. 26-41.

Nair, Anand (2006), "Meta-Analysis of the Relationship Between Quality Management Practices and Firm Performance - Implications for Quality Management Theory Development", Journal of Operations Management, Vol. 24, No. 6, pp. 948-975.

Peteraf, Margaret (1993), "The Cornerstones of Competitive Advantage: A Resource-Based View", Strategic Management Journal, Vol. 14, No. 3, pp. 179-191.
Pignanelli, Alexandre (2006), “O Impacto da Adoção de Critérios de Excelência na Maximização da Riqueza dos Acionistas". In: Simpósio de Administração da Produção, Logística e Operações Internacionais, 2006, São Paulo. Proceedings. SIMPOI.

Powell, Thomas C. (1995), "Total Quality Management as Competitive Advantage: A Review and Empirical Study", Strategic Management Journal, Vol. 16, No. 1, pp. 15-37.

Rahman, Shams-Ur. (2004), "The Future of TQM is Past. Can TQM be Resurrected?", Total Quality Management $\mathcal{E}$ Business Excellence, Vol. 15, No. 4, pp. 411-422.

Reeves, Carol A. and David A. Bednar (1994), “Defining Quality: Alternatives and Implications", The Academy of Management Review, Vol. 19, No. 3, pp. 419-445.

Reger, Rhonda K., Loren T. Gustafson, Samuel M. Demarie and John V. Mullane (1994), "Reframing the Organization: Why Implementing Total Quality Is Easier Said Than Done", The Academy of Management Review, Vol. 19, No. 3, pp. 565-584.

Rumelt, Richard P. (1991), "How Much Does Industry Matter?", Strategic Management Journal, Vol. 12, No. 3, pp. 167-185.

Rumelt, Richard P. (1984), "Towards a Strategic Theory of the Firm?". In: Robert Lamb (Ed.). Competitive Strategic Management. Englewood Cliffs, NJ: Prentice-Hall.

Staw, Barry M. and Lisa D. Epstein (2000), “What Bandwagons Bring: Effects of Popular Management Techniques on Corporate Performance, Reputation, and CEO Pay", Administrative Science Quarterly, Vol. 45, No. 3, pp. 523-556.

Venkatraman, N. and Vasudevan Ramanujam (1986), “Measurement of Business Performance in Strategy Research: A Comparison of Approaches", The Academy of Management Review, Vol. 11, No. 4, pp. 801-814.

Wernerfelt, Birger. (1984), "A Resource-Based View of the Firm", Strategic Management Journal, Vol. 5, No. 2, pp. 171-180.

Wilson, Darryl D. and David A. Collier (2000), "An Empirical Investigation of the Malcolm Baldrige National Quality Award Causal Model", Decision Sciences, Vol. 31, No. 2, pp. 361-390.

York, Kenneth M. and Cynthia E. Miree (2004), "Causation or Covariation: An Empirical Re-Examination of the Link Between TQM and Financial Performance", Journal of Operations Management, Vol. 22, No. 3, pp. 291-311.

\section{AUTHOR'S BIOGRAPHY}

Alexandre Pignanelli - Ph. D. student and Professor at Department of Operations and Production Management, Escola de Administração de Empresas de São Paulo, Fundação Getulio Vargas (FGV-EAESP). He has a Master's degree in Business Administration from FGV-EAESP and a Bachelor's degree in Mechanical Engineering from Universidade Estadual de Campinas (Unicamp).

João Mario Csillag - Professor at Department of Operations and Production Management, Escola de Administração de Empresas de São Paulo, Fundação Getulio Vargas (FGV-EAESP). He has a Ph. D. and a Master's degree in Business Administration from FGV-EAESP and a Bachelor's degree in Aeronautical Engineering from Instituto Tecnológico da Aeronáutica (ITA). 